\title{
ON THE IMPACT OF DIFFERENT SYSTEM STRATEGIES ON THE MATERIAL PERFORMANCE OF SELECTIVE LASER MELTING- MANUFACTURED TI6AL4V COMPONENTS
}

\author{
D. Dimitrov ${ }^{1}$, T.H. Becker ${ }^{2 *}$, I. Yadroitsev ${ }^{3} \&$ G. Booysen ${ }^{3}$
}

\section{ARTICLE INFO}

\section{Article details}

Presented at the $17^{\text {th }}$ annual

international conference of the Rapid

Product Development Association of

South Africa (RAPDASA), held from 2-4

November 2016 in Vanderbijlpark, South Africa

Available online

11 Nov 2016

\section{Contact details}

Corresponding author

tbecker@sun.ac.za

Author affiliations

1 Stellenbosch Technology Centre

Laboratory for Advanced

Manufacturing, Department of Industrial Engineering, Stellenbosch University, South Africa

2 Materials Engineering group, Department of Mechanical and Mechatronic Engineering, Stellenbosch University, South Africa

3 Centre for Rapid Prototyping and Manufacturing, Central University of Technology, Bloemfontein, South Africa

DOI

http://dx.doi.org/10.7166/27-3-1664

\section{ABSTRACT}

Selective Laser Melting (SLM) is a powder-based additive manufacturing process that has gained substantial interest in recent years due to its feasibility of producing geometricallycomplex metallic components for end-use in various industries, with or without post-treatment procedures. This paper presents recent research undertaken on different scanning strategies and process parameters with the purpose of providing an overview of the achievable material performance of Ti6Al4V components, and comparing its properties with the conventionally-produced parts. In order to understand their output, differences in the building strategies of the systems studied are analysed, and their influence on the resulting mechanical and metallurgical properties is highlighted.

\section{OPSOMMING}

Selektiewe lasersmelting is 'n poeiergebaseerde toevoegingsvervaardigingsproses wat onlangs wesenlike belangstelling gewek het as gevolg van die vermoë om geometries ingewikkelde metaal komponente te produseer sonder dat daar agteraf verdere behandelinge toegepas moet word. Navorsing oor verskillende skandeerstrategieë en proses parameters en hul invloed op die bereikbare materiaaleienskappe van Ti6Al4V komponente word voorgehou. Die materiaaleienskappe word vergelyk met dié van komponente wat met konvensionele tegnieke vervaardig is. Om die uitset beter te verstaan, word verskille in die bou-strategieë van die stelsels bestudeer en analiseer, om sodoende hul invloed op die gevolglike meganiese- en metallurgiese eienskappe te bepaal.

\section{INTRODUCTION}

Manufacturing industries constantly strive to improve their production capabilities, including reduction in lead-time, cost-saving, and improved waste control. Advanced technologies such as additive manufacturing (AM) can help to meet such demands. With the advent of new materials along with new processes, each technology has contributed to the diversity in different fields of application. Throughout the process of technological advancement, it is critical to understand the capabilities of each individual technology in order to compare and improve current processes and techniques, and to be able to give clear guidelines to product designers and component manufacturers.

This is of particular importance for additive processes that convert metallic powders into solid objects, such as selective laser sintering/selective laser melting (SLS/SLM), electron beam melting (EBM), and others, which enable them to deliver final products in single or low to medium production runs. Thus it is no coincidence that in recent years the aforementioned processes are of specific interest to various academic and industrial research groups. A large number of publications on this subject are available. Some of this literature has a fundamental or overviewing character [1, 2], whereas other literature deals in particular with issues related to the improvement of product 
properties or process performance [3-7]. However, there has been no comprehensive study of the process physics and how differences in the scanning approach influence the process outcome.

This paper forms part of a large research programme, the Collaborative Programme in Additive Manufacturing (CPAM), which aims to establish and compare the capabilities of the SLM process. Specific to the South African context, the SLM technology is intended for use in biomedical and aerospace applications. It reports on certain aspects of achievable material performance of components manufactured by processing Ti6Al4V powder and applying different scanning strategies and process parameters. A further objective of the paper is to contribute to the establishment of databases containing the kind of reliable data that product and process design requires.

\section{COMPARATIVE ANALYSIS OF STUDIED SCANNING AND PROCESS PARAMETERS}

In this study, two different scanning strategies were investigated. Selected parameters were maximally different, in order to be able to understand better how they affect the mechanical properties of the final product. For comparative purposes, the results published by Leuders et al. [4] are also taken in account. Details of the applied scanning strategy (referred to as 'Strategy 3') and parameter set were not accessible. The most important data of the studied process parameters are summarised in Table 1.

\section{Table 1: Parameters of the studied scanning strategies}

\begin{tabular}{|l|c|c|c|}
\hline Main parameters & Strategy 1 & Strategy 2 & Strategy 3 \\
\hline Laser power, $\mathrm{W}$ & 150 & 100 & $400 \mathrm{max}$ \\
\hline Scanning speed, $\mathrm{m} / \mathrm{s}$ & 1.2 & 0.6 & - \\
\hline Focus spot diameter, $\mu \mathrm{m}$ & 100 & 150 & - \\
\hline Laser power density, $\mathrm{MW} / \mathrm{cm}^{2}$ & 1.5 & 0.44 & - \\
\hline Linear energy input, $\mathrm{J} / \mathrm{m}$ & 125 & 167 & - \\
\hline Platform heating & Ambient & Ambient & $100^{\circ} \mathrm{C}$ \\
\hline
\end{tabular}

In Strategy 1 , each cross-section of the sample is divided into strips with a width of typically $5 \mathrm{~mm}$. Consistently, track by track ( $a, b, c$, etc.) and strip by strip (A, B, C, etc.), as indicated in Figure $1 \mathrm{a}$, the entire cross-section is exposed by the laser beam. The scan direction in each successive layer is rotated by unknown degrees relative to the previous layer. Specimens manufactured under Strategy 1's parameters were produced by the Centre of Rapid Prototyping and Manufacturing (CRPM) at the Central University of Technology. The CRPM uses an EOSINT M280 system that uses a standard setting supplied by EOS.

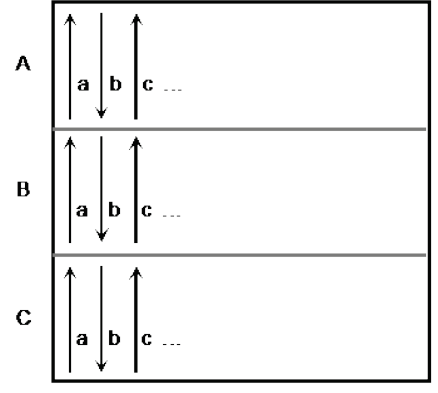

(a)

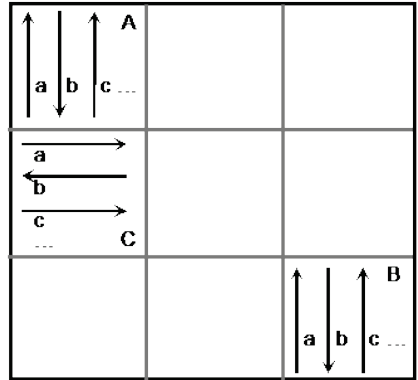

(b)

Figure 1: Implemented scanning strategies, showing (a) strategy 1 and (b) strategy 2.

In Strategy 2, or each cross-section of the sample is divided into square regions (islands) of $5 \times 5 \mathrm{~mm}$. Each building section is fully completed before the laser moves to another non-adjacent section (Figure 1b). The scan direction at adjacent sections is rotated 90 degrees to form a checkerboard type pattern. Each layer is offset by $1 \mathrm{~mm}$ relative to the previous layer. Strategy 2's specimens were built using the CONCEPT Laser GmbH M2 LaserCusing system at the University of Stellenbosch.

In both cases, the powder layer thickness was $30 \mu \mathrm{m}$, and the working platform (substrate) did not have a preheating option. 
In Strategy 3, the study did not explicitly state the exposure strategy. However, it is known that an SLM 250HL machine was used to fabricate specimens with a heated platform of $100^{\circ} \mathrm{C}$. Strategy 3 was taken from the published worked by Leuders et al. [7] in Germany.

Table 1 shows that Strategies 1 and 2 have a similar linear energy input, while the laser power density and scanning speed differ by more than two to three times. Using the SLM model described in Yadroitsev et al. [8], temperature fields (Figure 2a) and temperature profiles (Figure 2b) were calculated for a single scan track. The numerical simulations indicated that a larger depth of the molten pool and a higher maximum temperature was achieved for Strategy 1 than for Strategy 2 . Furthermore, the respective cooling rates show that Strategy 2 results in a somewhat slower cooling rate.
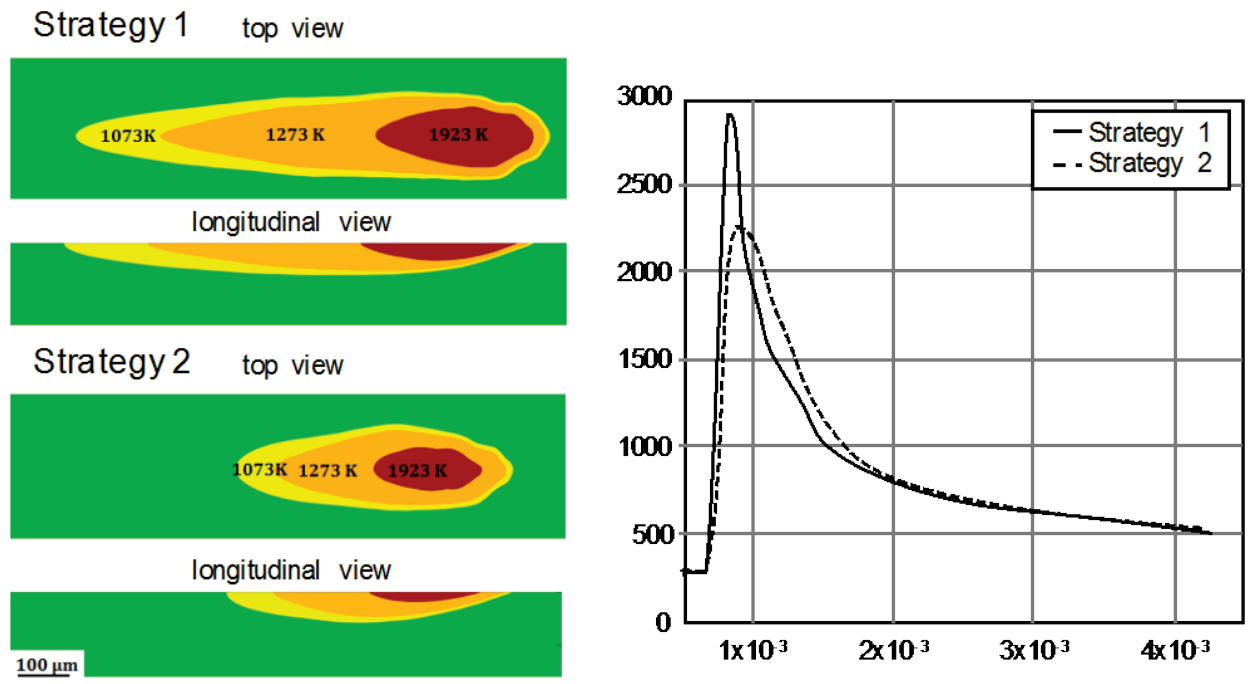

Figure 2: Temperature distributions (a) and profiles (b) of single scan track at different strategies.

This preliminary analysis indicates that the significant difference in temperature distributions, temperature gradients, and cooling rates attributed to the building strategy applied can lead to substantial differences in the resulting residual stresses and in the microstructure of the manufactured parts.

\section{MATERIAL PERFORMANCE OF MANUFACTURED COMPONENTS}

The material performance investigation aims to determine the achievable mechanical properties resulting from scanning Strategies 1 and 2, compared with Strategy 3 as mentioned above. In addition, post-treatment conditions (heat treatment) typically used to improve the material performance of SLM components are considered. Characteristic quasi-static, crack growth behaviour, residual stresses, and the microstructural interaction with the mentioned properties are investigated.

\subsection{Experimental evaluation details}

As mentioned earlier, details of the scanning strategies are given in Table 1 and Figure 1. For Strategy 2, samples were built by applying both a single and a double exposure (the same layer is exposed twice by the laser beam). The samples were post-machined to ensure that the required tolerances and surface finish were achieved as dictated by the standards.

Four different microstructural conditions of the Ti6AL4V alloy were considered: the as-built condition, and three heat-treated conditions, including a recrystallization anneal (RA) in vacuum, hot isostatic pressing (HIP) in an argon gas atmosphere, and a beta anneal (BA) in vacuum. Details are provided in Table 2. 
Table 2: Material properties obtained for the different strategies and heat treatments

\begin{tabular}{|c|c|c|c|c|c|c|}
\hline $\begin{array}{l}\text { Scanning } \\
\text { strategy }\end{array}$ & Heat treatment & $\begin{array}{c}\text { Residual } \\
\text { stress } \\
\text { [MPa] } \\
\end{array}$ & $\begin{array}{c}\text { Yield } \\
\text { strength } \\
{[\mathrm{MPa}]} \\
\end{array}$ & $\begin{array}{l}\text { UTS } \\
{[\mathrm{MPa}]}\end{array}$ & $\begin{array}{c}\text { Elongation at } \\
\text { break } \\
{[\%]} \\
\end{array}$ & $\begin{array}{c}\mathbf{K}_{\mathrm{lc}} \\
{[\mathrm{MPa} / \mathrm{m}]}\end{array}$ \\
\hline \multirow{4}{*}{ Strategy 1} & As built: - & 1010 & 1150 & 1155 & 4.1 & 37 \\
\hline & $\begin{array}{l}\text { RA: } 950^{\circ} \mathrm{C} \text { for } 2 \mathrm{hr} \text {, } \\
\text { furnace cooled at } 5 \\
{ }^{\circ} \mathrm{C} / \mathrm{min} \text {. }\end{array}$ & - & 870 & 915 & 10.3 & $86^{*}$ \\
\hline & $\begin{array}{l}\text { HIP: } 915^{\circ} \mathrm{C} \text { at } 105 \mathrm{MPa} \\
\text { for } 2 \mathrm{hr} \text {, cooled at } \\
11^{\circ} \mathrm{C} / \mathrm{min} \text {. }\end{array}$ & - & 920 & 960 & 8.5 & 58 \\
\hline & $\begin{array}{l}\text { BA: } 1030^{\circ} \mathrm{C} \text { for } 1 \mathrm{hr} \text {, air } \\
\text { cooled. } 630 \text { for } 1 \mathrm{hr} \text {, air } \\
\text { cooled. }\end{array}$ & - & - & 1010 & 10.4 & - \\
\hline \multirow[b]{2}{*}{$\begin{array}{l}\text { Strategy } 2 \text {, } \\
\text { single exposure }\end{array}$} & As built: - & 320 & 1100 & 1215 & 8.9 & 28 \\
\hline & $\begin{array}{l}\text { RA: } 950^{\circ} \mathrm{C} \text { for } 2 \mathrm{hr} \text {, } \\
\text { furnace cooled at } 5 \\
{ }^{\circ} \mathrm{C} / \mathrm{min} \text {. }\end{array}$ & - & 900 & 965 & 10.7 & 67 \\
\hline \multirow{2}{*}{$\begin{array}{l}\text { Strategy } 2 \text {, } \\
\text { double } \\
\text { exposure }\end{array}$} & As built: - & 270 & 1150 & 1260 & 7.2 & 34 \\
\hline & $\begin{array}{l}\text { RA: } 950^{\circ} \mathrm{C} \text { for } 2 \mathrm{hr} \text {, } \\
\text { furnace cooled at } 5 \\
{ }^{\circ} \mathrm{C} / \mathrm{min} \text {. }\end{array}$ & - & 890 & 950 & 11.7 & 66 \\
\hline \multirow{4}{*}{ Strategy 3} & As built: - & 775 & 1195 & 1269 & 1.6 & - \\
\hline & $\begin{array}{l}\text { RA: } 800^{\circ} \mathrm{C} \text { for } 2 \mathrm{hr} \text {, } \\
\text { furnace cooled. }\end{array}$ & - & 962 & 1040 & 5 & - \\
\hline & $\begin{array}{l}\text { HIP: } 920^{\circ} \mathrm{C} \text { at } 100 \mathrm{MPa} \\
\text { for } 2 \mathrm{hr} \text {, furnace cooled. }\end{array}$ & - & 912 & 1005 & 8.3 & - \\
\hline & $\begin{array}{l}\text { BA: } 1050^{\circ} \mathrm{C} \text { for } 2 \mathrm{hr} \text {, } \\
\text { furnace cooled. }\end{array}$ & - & 798 & 945 & 11.6 & - \\
\hline
\end{tabular}

${ }^{*} \mathrm{P}_{\max } / \mathrm{P}_{\mathrm{Q}} \leq 1.1$ not achieved.

Porosity investigations were undertaken using either the Archimedes principle (ASTM B311) or an industrial computed tomography (CT) scanner. The CT scanner is a General Electric Phoenix V|Tome|X L240 with an additional NF180 option. In this study, $5 \mathrm{~mm}$ diameter cylinders were scanned, allowing for a voxel resolution of $3 \mu \mathrm{m}^{3}$.

Residual stresses were measured using the hole drilling strain gauge method according to ASTM E 837. The drilling equipment used in this study was a Micro-Measurements RS-200 Optical drilling system with an air-turbine high-speed drill attachment. The strain gauges were Micro-Measurements CEA-06-062UM-120 rosettes. Measurements were taken in the XY plane orientation. Since it is expected that strain measurements will show high levels of deviation from a uniform stress state, a non-uniform procedure was implemented [9].

Characterisation of the quasi-static properties was performed according to ASTM E8/E8M. Tests were conducted using the Zwick/Roell 1484 in ambient conditions. The tensile properties investigated were yield strength, ultimate tensile strength (UTS), and percentage elongation at break. A minimum of five round tensile specimens (with a gauge diameter of $4.00 \mathrm{~mm}$ ) were tested in the $Y$ orientation. All tests were displacement-controlled at a strain rate of $0.0011 / \mathrm{s}$.

An analysis of crack growth behaviour was conducted in ambient conditions with a load ratio of $\mathrm{R} \approx$ 0.1. The specimens were manufactured according to ASTM E 647 with $\mathrm{W}=25 \mathrm{~mm}$ and $\mathrm{B}=12.5 \mathrm{~mm}$. An optical microscope was used to monitor crack propagation, which allowed for crack measurements to be taken every $0.1 \mathrm{~mm}$. Five specimens were tested in the as-built condition, five in the recrystallisation annealed condition for each process respectively, and five in the HIPed condition. The specimens were orientated so that the crack propagation was in the XZ plane. Tests were carried out at a frequency of $10 \mathrm{~Hz}$.

Fracture toughness tests were conducted according to ASTM E399. The same samples were used for both fracture toughness tests and crack growth rate investigations. Thus the fatigue crack length 
was restricted to the range from $\mathrm{a} / \mathrm{W}=0.45$ to $\mathrm{a} / \mathrm{W}=0.55$ for $\mathrm{K}_{\mathrm{lc}}$ determination. The fracture toughness tests were displacement-controlled at a rate of $1 \mathrm{~mm} / \mathrm{min}$.

\subsection{Microstructure evaluation}

Previous studies $[10,11]$ have shown that the as-built condition microstructure has a very fine acicular (plate-like) morphology. This is attributed to the inherently rapid cooling rate of the material during the laser melting process, which results in the beta to martensite transition. Because of the very large solidification under cooling, the microstructure may be interpreted as martensitic. A fine acicular morphology was confirmed for both Strategies 1 and 2 (Figure $3 a$ and $3 b$ ), and has also been observed by other researchers [4, 12]. Strategy 2's as-built microstructure shows somewhat less fine morphology, which suggests a slower cooling rate that may be attributed to the stochastic sequence selection as applied in this building strategy.
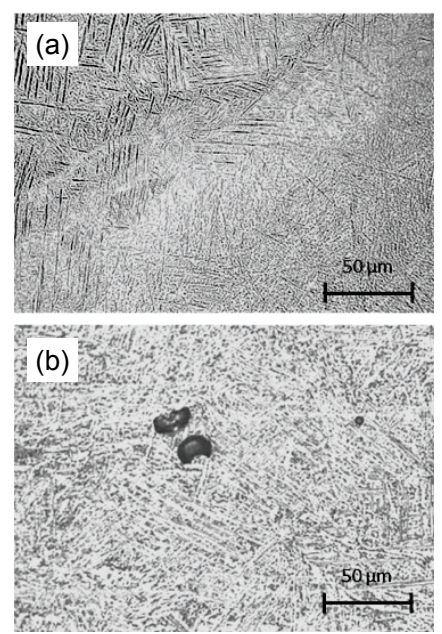
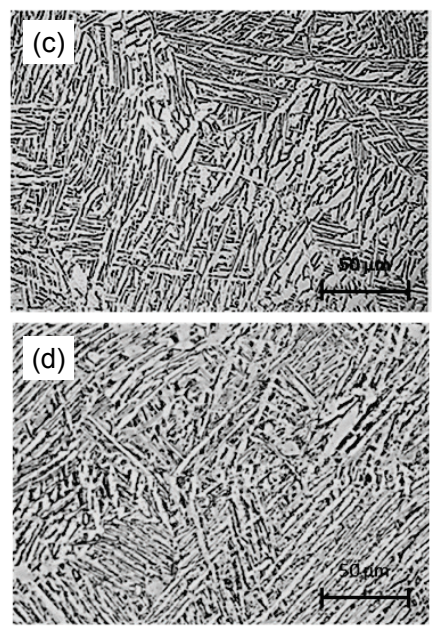
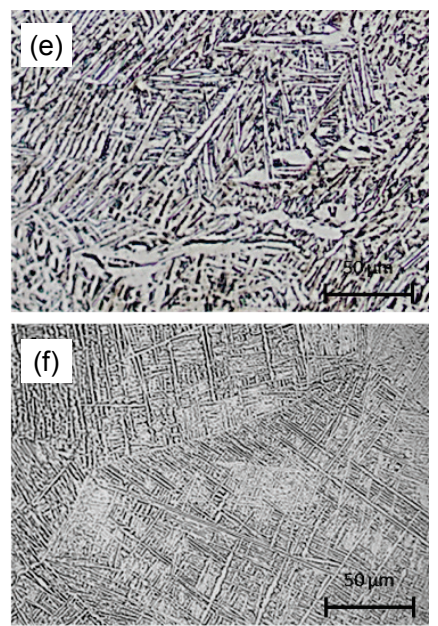

Figure 3: Microstructures obtained for as-built condition $(a, b)$ and through various heat treatments: (c) and (d) in the recrystallisation annealed condition (e) for the HIPed, and (f) for BA conditions; respectively for Strategy 1 (a, c, e, f) and for Strategy 2 (b, d).

The RA (Figure $3 c$ and $3 \mathrm{~d}$ ) showed a transformed microstructure into a plate-like alpha and beta, consisting of a small amount of equiaxed alpha phase. Both Strategies 1 and 2 responded similarly to this heat treatment. This alpha and beta is different from wrought Ti-6Al-4V in that it shows an acicular structure with widening of the transformed alpha laths. As expected, a HIPed condition shows a similar morphology (Figure 3e).

The microstructural change in the BA produced a fine microstructure consisting of acicular alpha with the alpha phase preferentially along the prior beta grains (Figure 3f). The 'fineness' of this microstructure is evidence of a moderate cooling rate from above the beta transus. Also important to note is that the alpha laths have preferential orientations based on the Burgers' orientation relationship.

\subsection{Density and porosity distribution}

High densities of $99.79 \pm 0.1$ per cent and $99.81 \pm 0.1$ per cent are achievable for Strategies 1 and 2 respectively; a similar density of 99.77 per cent is reported in Leuders et al. [4]. A near full density of $99.94 \pm 0.1$ per cent was achieved for HIPed samples, with no visible porosity in CT scans, which suggests that any residual porosity is below the CT scan resolution limit.

CT scans show an even porosity distribution with no indication of a dependence on layer distribution or sample orientation for Strategy 1. However, a distinct porosity distribution pattern was observed in Strategy 2. The distance between pores coincides with the hatch spacing and 'island' building strategy; smaller pores are aligned with the hatch spacing, and larger pores coincide with the layer island offset spacing of $1 \mathrm{~mm}$. This type of aligned pores formation might be attributed to an unsuitable scan spacing [2]. 


\subsection{Residual stresses}

Residual stress measurements are summarised in Table 2 above, and show that significant residual stresses exist in the as-built condition when applying Strategy 1 . The stress distributions were highly non-uniform, and their depth profiles show relatively little consistency between the specimens. As expected, the heat-treatment significantly reduces residual stress. It is interesting to note the significantly lower stresses measured for Strategy 2, which may be attributed to the stochastic sequences of the exposure of the sections (islands) and a considerably lower temperature gradient.

\subsection{Quasi-static properties}

The achievable quasi-static strengths for the post-treatments are summarised in Table 2. Standard deviations are $\pm 20 \mathrm{MPa}$ for UTS and yield strength and \pm 2 per cent for elongation at break. The asbuilt samples achieved the higher value of tensile strength in comparison to the heat-treated (RA, HIP, and BA) specimens. Furthermore, the ductility (percentage elongation) has increased through the various heat treatments. The results are consistent with the microstructural observations in the fact that the larger grain structures provided a decrease in strength and an increase in ductility. The as-built material has an increased strength, compared to the wrought metal, which can be attributed to the fine acicular microstructure.

The fracture toughness results are also presented in Table 2 above. The as-built material condition resulted in surprisingly low toughness, with the RA condition having the highest toughness, comparable to wrought mill-annealed Ti6Al4V.

\subsection{Crack growth behaviour}

The crack growth measurements for the considered strategies are shown in Figure 4. A substantial difference between the as-built and heat-treated material condition can be observed. The as-built condition has considerably poorer fatigue performance than the heat-treated condition (identified by the faster crack growth rate for a similar cyclic stress intensity factor value) and exhibits large scatter. Specimens in both the RA and the HIP conditions have significantly less scatter and a similar behaviour to that of the wrought mill-annealed metal. The scatter in the data might be attributed to high residual stresses that are present in the as-built state.

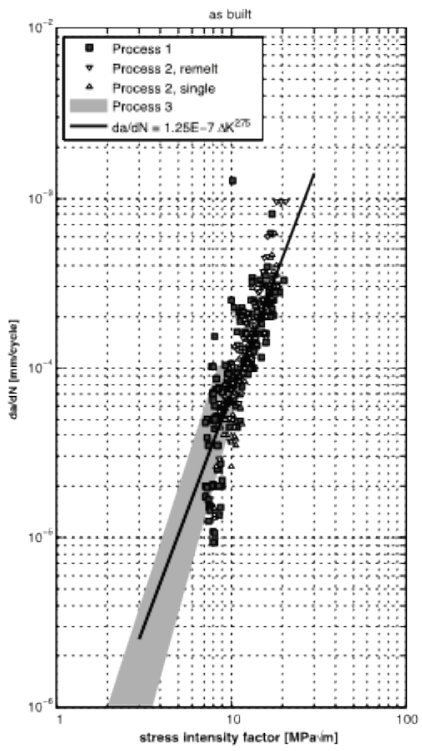

(a)

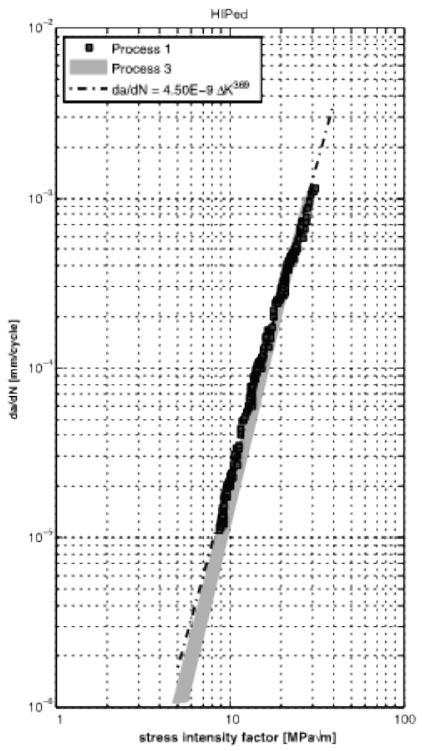

(b)

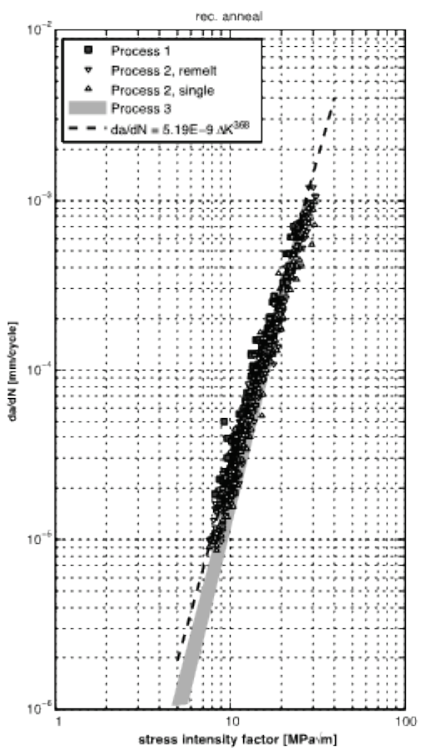

(c)

Figure 4: Crack growth behaviour in the (a) as-built, (b) recrystallisation anneal, and (c) HIPed condition.

Similarly to the quasi-static properties, the processing and microstructure can have a large effect on the crack growth rate. Generally for wrought metal, fine BA microstructures in near-alpha and alpha-beta have the lowest fatigue crack growth rates, whereas mill-annealed microstructures yield 
the highest growth rates. A martensitic alpha microstructure can be advantageous; however, in the case of laser melting, the high residual stresses outweigh any advantageous microstructural effects.

\section{MATERIAL PERFORMANCE OPTIMISATION}

A significant improvement in the material performance of SLM Ti6Al4V can be achieved by an appropriate treatment from a residual stress, ductility, toughness, and the crack growth point of view. To obtain high strength with adequate ductility, heat treatment below the beta transus is suggested, as heat treating in the beta range can cause significant loss in strength. Typically for wrought Ti6Al4V, a heat treatment just below the beta transus can obtain an optimum balance of ductility, fracture toughness, and tensile strength. This can be clearly observed when studying the data shown in Table 2 and Figure 4.

However, the requirements for material performance are often application-specific, and in many instances there are still significant concerns over porosity, microstructure, high residual stresses, and fatigue strength. Standard heat treatments may not apply to SLM-produced components. The microstructure of Ti6Al4V - and hence its mechanical properties - depend on the process history. Since as-built SLM Ti6Al4V has a fine acicular morphology arising from heating above the beta transus, improper heat-treatment can result in undesirable properties. Because cracks tend to propagate in or near interfaces, this type of structure can provide loci for crack initiation and propagation, and so lead to premature failure. BA microstructures are reported to have the lowest fatigue crack growth rates, whereas as-built microstructures yield the highest growth rates [4].

\section{CONCLUSION}

The main objective of this study was to establish the impact of different scanning strategies and process parameters on the material performance of SLM-manufactured Ti6Al4V components. The most important conclusions can be summarised as follows:

- The considered scanning strategies and process parameter sets yield near-full densities of the manufactured SLM samples, and provide comparable mechanical properties.

- $\quad$ The applied building strategy, including Strategy 3, clearly influences the level of the residual stresses. It is an important avenue for future research work.

- $\quad$ Significant improvement in mechanical properties can be achieved by an appropriate posttreatment. However, different heat-treatment conditions have to be investigated in a specific context, and their impact on the final product qualities evaluated from a technological and an economical perspective.

\section{ACKNOWLEDGEMENTS}

The authors acknowledge funding by the Department of Science and Technology through the Collaborative Programme in Additive Manufacturing (CPAM).

\section{REFERENCES}

[1] Kruth, J.P., Levy, G., Klocke, F. and Childs, T.H.C. 2007. Consolidation phenomena in laser and powderbed based layered manufacturing. Annals of the CIRP, 56(2), pp. 730-759.

[2] Kruth, J.P., Badrossamay, M., Yasa, E., Deckers, J., Thijs, L. and Van Humbeeck, J. 2010. Part and material properties in selective laser melting of metals. Proceedings of the 16th Int. Symposium on Electro machining, Leuven, Belgium.

[3] Brinksmeier, E., Levy, G., Meyer, D. and Spierings, A.B. 2010. Surface integrity of selective-laser-melted components. Annals of the CIRP, 59(1), pp. 601-606.

[4] Leuders, S., Thöne, M., Riemer A., Niendorf T., Tröster T., Richard, H.A. and Maier, H.J. 2013. On the mechanical behaviour of titanium alloy TiAl6V4 manufactured by selective laser melting: Fatigue resistance and crack growth performance. International Journal of Fatigue, 48, pp. 300-307.

[5] Rafi, H.K., Karthik, N.V., Haijun, G., Starr, T.L. and Stucker,B.E. 2013. Microstructures and mechanical properties of Ti6Al4V parts fabricated by selective laser melting and electron beam melting. Journal of Materials Engineering and Performance, 22(12), pp. 3872-3883.

[6] Jahn, S., Sändig, S., Gemse, F., Straube, C., Emmelmann, C. and Seyda, V. 2014. Heat treatment of selective laser melted titanium parts. Proceedings from the Direct Digital Manufacturing Conference, March 12-13, Berlin, Germany. 
[7] Yadroitsev, I., Krakhmalev, P., Yadroitsava, I., Johansson, S. and Smurov, I. 2013. Energy input effect on morphology and microstructure of selective laser melting single track from metallic powder. Journal of Materials Processing Technology, 213(4), pp. 606-613

[8] Yadroitsev, I., Krakhmalev, P. and Yadroitsava, I., 2015. Hierarchical design principles of selective laser melting for high quality metallic objects. Additive Manufacturing, 7, pp. 45-56.

[9] Moharami, R. and Sattari-Far, I. 2008. Experimental and numerical study of measuring high welding residual stresses by using the blind-hole-drilling technique. Journal of Strain Analysis for Engineering Design, 43(3), pp. 141-148.

[10] Facchini, L., Magalini, E., Robotti, P., Molinari, A., Höges, S. and Wissenbach, K. 2010. Ductility of a Ti$6 \mathrm{Al}-4 \mathrm{~V}$ alloy produced by selective laser melting of pre-alloyed powders. Rapid Prototyping Journal, 16(6), pp. 450-459.

[11] Jovanovic, M.T., Tadic, S., Zec, S., Miskovic, Z. and Bobic, I., 2006. The effect of annealing temperatures and cooling rate on microstructure and mechanical properties of investment cast Ti6Al4V alloy. Materials and Design, 27, pp. 192-199.

[12] Vrancken, B., Thijs, L., Kruth, J.-P. and Van Humbeeck, J., 2012. Heat treatment of Ti6Al4V produced by selective laser melting: Microstructure and mechanical properties. Journal of Alloys and Compounds, 541, pp. 177-185. 